\title{
Effect of supplementary feeding on the growth and economics of feeding of kids under semi-arid conditions
}

\author{
BS Khadda, Kanak Lata, Raj Kumar, JK Jadav \& P Kalas
}

Journal of Agriculture and Ecology

\section{Journal of Agriculture} and Ecology

ISSN: 2456-9410

Volume: 5

Journal of Agriculture and Ecology (2018) 5: 61-66 http://doi.org/10.53911/JAE.2018.5107 


\title{
Effect of supplementary feeding on the growth and economics of feeding of kids under semi-arid conditions
}

\author{
BS Khadda $\varnothing$, Kanak Lata, Raj Kumar, JK Jadav \& P Kalas \\ ICAR-Krishi Vigyan Kendra (CIAH), Panchmahal, \\ Godhra-Baroda Highway, Vejalpur-389 340 (Gujarat) \\ Corresponding author: BS Khadda, E-mail khadda74@gmail.com
}

\section{Article Info \\ Article history \\ Received: 07 May 2018 \\ Accepted: 30 May 2018 \\ Available online: 15 June \\ 2018}

Key Words: Body
weight, concentrate
mixture, feed, growing
goats, mineral mixture,
semi- arid.

\begin{abstract}
A trial was conducted at KVK- Panchmahal, Gujarat, India, to assess the effect of supplementation of concentrate and mineral mixture on growth of goats under semi-arid field condition. Thirty Gohilwadi growing kids (3-4 month old) were randomly divided into three groups of ten each. Group $\mathrm{T}_{1}$ (goats kept under sole grazing), $\mathrm{T}_{2}$ (goats fed $150 \mathrm{~g}$ concentrate mixture), and $\mathrm{T}_{3}$ (goats fed $150 \mathrm{~g}$ concentrate mixture and $10 \mathrm{~g}$ mineral mixture in addition to grazing). The duration of experimental feeding was 90 days in all the groups. Total weight gain in $\mathrm{T}_{1}, \mathrm{~T}_{2}$ and $\mathrm{T}_{3}$ group was $3.22 \pm 0.98$, $6.36 \pm 0.42$ and $7.15 \pm 0.58 \mathrm{~kg}$, respectively of experiment feeding after 90 days. Average daily gain (g) was $35.83 \pm 7.22$, 70.66 \pm 4.67 and $79.44 \pm 6.47$ in $\mathrm{T}_{1}, \mathrm{~T}_{2}$ and $\mathrm{T}_{3}$, respectively. The kids in supplemented group $\left(\mathrm{T}_{2}\right.$ and $\left.\mathrm{T}_{3}\right)$ achieved significantly higher body weight $(17.42 \pm .0 .49$ and $18.55 \pm 0.66 \mathrm{~kg}$.) than the non-supplemented group (14.52 \pm 0.96$)$. The net return from group $\mathrm{T}_{2}$ and $\mathrm{T}_{3}$ was significantly higher as compared $\mathrm{T}_{1}$. It could be concluded that supplementary feeding of concentrate and mineral mixture to the growing goats improve the growth performance of goats.
\end{abstract}

Copyright ( 2018 Khadda et al., This is an open access article published under the terms of the Creative Commons Attribution License, which permits unrestricted use, distribution, and reproduction in any medium, provided the original work is properly cited.

Preferred citation: Khadda BS, Kanak Lata, Raj Kumar, Jadav JK \& Kalas P 2018. Effect of supplementary feeding on the growth and feeding economics of kids under semi-arid conditions. Journal of Agriculture and Ecology, 5: 61-66; http://doi.org/10.53911/JAE.2018.5107.

\section{Introduction}

Goats are reared mainly on the grazing on the community pasture and harvested cropped land. As a result of changing land use pattern and reduction of grazing land, maintenance of goats with zero input is becoming difficult. Therefore, rearing of goats on intensive or semi-intensive system of management remain the only viable options. However, goat rearer's in semi-arid regions do not provide concentrate and mineral mixture to their goats even in the critical physiological stages such as growth (Khadda et al. 2009; Khadda et al. 2016). Therefore, growth performance of goats becomes poor and less profitable on account of lower dressing percentage and meat bone ratio. Supplementation of concentrate mixture to kids increases the growth rate, shortens the slaughter age, increase dressing yield, and improves carcass quality and sensory panel evaluation of tenderness. Minerals are essential constituents 
of feed and play an important role in nutrient utilization, growth and production. Mineral supplimented feeds are utilized efficiently in animal system. Mineral status of feed and fodder is influenced by soil and environmental conditions while their requirement varies according to the physiological and productive status of animals (Tripathi \& Karim 2008). However, the information available on the effect of supplementation of concentrate and mineral mixture on growth of growing kids under field condition is scanty. Therefore, the present investigation was undertaken to demonstrate the usefulness of concentrate and mineral mixture supplementation on growth performance of kids.

\section{Materials and Methods}

Growth trial was conducted at KVKPanchmahal under the semi- arid condition of Gujarat, India, to assess the effect of supplementation of concentrate and mineral mixture on growth of kids under field conditions. Thirty Gohilwadi kids of 3 to 4 months of age were randomly selected and distributed equally into three groups i.e. $\mathrm{T}_{1}$ (kids were maintained on sole grazing for 8 hrs on community grazing land, $\mathrm{T}_{2}$, (kids were fed $150 \mathrm{~g}$ concentrate mixture besides grazing on community grazing land) and $\mathrm{T}_{3}$ (kids were fed $150 \mathrm{~g}$ concentrate mixture $+10 \mathrm{~g}$ mineral mixture besides grazing). The concentrate mixture contained barley $20 \%$, maize $20 \%$, mustard cake $20 \%$, cotton seed cake $15 \%$, deoiled rice brain $12 \%$, rice polish $10 \%$, mineral mixture $2 \%$ and common salt $1 \%$. All the kids were dewormed before initiation of the experiment. Fresh and clean drinking water was provided ad libitum twice daily throughout the experiment. The trial was conducted for 90 days from mid-November, 2011 to mid-February, 2012. The body weights of growing kids were recorded at monthly interval. Representative samples of concentrate mixture and straws were analyzed for dry matter (DM) by drying in the hot air oven at $60{ }^{0} \mathrm{C}$ till constant weight. The sample were subsequently ground to pass through 1 $\mathrm{mm}$ sieve in a Wiley mill and analyzed for Ether extract (EE) crude fiber $(\mathrm{CF})$, crude protein (CP) and ash as per AOAC 2000. The mineral mixture used in the experiment was area specific and was procured from Panchmahal district co-operative milk producers union Ltd, Godhra. The data were in a completely randomized design and significances of difference between treatments means was determined using student-t test (Snedecor and Cochran, 1994). Partial budget analysis and benefit cost ratio was calculated to assess the economic profitability of supplementary fedding (Danilo 2002). The vegetation cover of community rangeland consisted of Cynodon dactylon (Dhub), Desmostachya bipinnata (Dab), Saccharum spontaneum (Kans), Cyperus rotundus (Motha), Trianthema manogyna (Pathar chatta) and Chinopodium album (Bathwa) grasses, Zizyphus spp. (Pala), Euphorbia spp.(Thur) Calotropic procera (Aak),shrubs and Prosopic juliflora (Israeli babool),Crotolaria burhia (legaria), Zyziphus jujuba (Ber), Acacia nilotica (Babool), Morus alba (Mulberry), Leucaena leucocephala (Subabool), Morus alba(Sahtut), Ficus religiosa (Peepal),Ficus benghalensis (Bargad), Ficus glomerata (Gular), Azardirachta indica (Neem), Tamarindus Indica (Tamarind) and Prosopis cineraria 
(Khejri) trees used as fodder. However, the diet of the goats consistence mainly tree leaves, dry and green grasses with little quantity of Sorghum bicolor (Jowar) and Pennisetum typhoides (Perlmillet) Stover.

\section{Result and Discussion}

Proximate composition of feed and fodder consumed by experimental goats is presented in Table 1. Most of the dry fodder available for feeding during experimental period was of medium quality and green fodder of good quality. The DM and OM content of basal roughage and green forages were similar to that of reported by Misra et al. (2006). The CP and CF content of dry and green fodder was higher to that of reported by Misra et al. (2006) and Choudhary \& Jat (2008). Concentrate mixture offered to experimental animals was of good quality. The DM, OM, $\mathrm{CP}$ and $\mathrm{CF}$ content in concentrate mixture were found 90.60, 88.96, 18.98 and 8.52 per cent, respectively.

Table 1. Proximate composition of feedstuffs used during the on farm trial (\% on DM basis)

\begin{tabular}{ccccccc}
\hline $\begin{array}{c}\text { Partic } \\
\text { ular }\end{array}$ & $\begin{array}{c}\text { Concentrate } \\
\text { mixture }\end{array}$ & $\begin{array}{c}\text { Sorghum } \\
\text { stover }\end{array}$ & $\begin{array}{c}\text { Perlmillet } \\
\text { stover }\end{array}$ & $\begin{array}{c}\text { Mixed dry } \\
\text { grass }\end{array}$ & $\begin{array}{c}\text { Mixed green } \\
\text { grass }\end{array}$ & $\begin{array}{c}\text { Mixed tree } \\
\text { leaves }\end{array}$ \\
\hline DM & $90.60 \pm 1.07$ & $90.25 \pm 1.07$ & $89.97 \pm 1.3$ & $88.65 \pm 1.35$ & $21.20 \pm 1.23$ & $24.60 \pm 4.13$ \\
OM & $88.96 \pm 2.11$ & $91.23 \pm 1.90$ & $90.18 \pm 1.7$ & $90.70 \pm 1.90$ & $90.68 \pm 1.56$ & $90.06 \pm 2.59$ \\
CP & $18.98 \pm 1.30$ & $5.11 \pm 0.70$ & $6.47 \pm 0.80$ & $7.37 \pm 0.60$ & $9.87 \pm 0.80$ & $13.72 \pm 3.20$ \\
CF & $8.52 \pm 1.020$ & $29.73 \pm 2.11$ & $33.56 \pm 1.9$ & $37.3 \pm 1.80$ & $31.12 \pm 2.1$ & $18.95 \pm 5.07$ \\
EE & $3.19 \pm 1.220$ & $1.09 \pm 0.30$ & $0.91 \pm 0.40$ & $1.96 \pm 0.60$ & $1.34 \pm 0.60$ & $2.11 \pm 0.58$ \\
NFE & $58.27 \pm 2.87$ & $55.30 \pm 2.51$ & $49.25 \pm 3.1$ & $55.93 \pm 2.3$ & $44.07 \pm 2.1$ & $55.28 \pm 2.91$ \\
Total & $11.04 \pm 0.90$ & $8.77 \pm 0.70$ & $9.82 \pm 0.60$ & $9.30 \pm 0.23$ & $13.60 \pm 0.40$ & $9.94 \pm 0.53$ \\
Ash & & & & & & \\
\hline
\end{tabular}

\section{Effect on body weight and growth performance}

The effect of supplementation on body weight is present in Table 2. The result of the study revealed that the maximum body weight of kids was attained by $\mathrm{T}_{3}(18.55 \pm 0.66 \mathrm{~kg}$.) followed by $\mathrm{T}_{2}\left(17.42 \pm .0 .49 \mathrm{~kg}\right.$.) and $\mathrm{T}_{1}$ $(14.52 \pm 0.96 \mathrm{~kg})$ after 90 days. These results are in accordance with the findings of Yadav et al. (2010). Similarly, effect of supplementation of concentrate mixture and herbage allowance on the performance of grazing suckling lambs has also been reported by Prache et al. (1990). The body weight of goats fed concentrate mixture with mineral mixture was improved considerably as compared to control (Fig. 1\& 2). The total weight gain over initial weight in $\mathrm{T}_{1}, \mathrm{~T}_{2}$ and $\mathrm{T}_{3}$ was $3.22 \pm 0.98,6.36 \pm 0.42$ and $7.15 \pm 0.58$ $\mathrm{kg}$ after 90 days, respectively. Average daily weight gain was recorded to be $35.83 \pm 7.22$, $70.66 \pm 4.67$ and $79.44 \pm 6.47 \mathrm{~g} /$ day in $\mathrm{T}_{1}, \mathrm{~T}_{2}$ and $\mathrm{T}_{3}$, respectively. Similar results were reported 
by Yadav et al. (2010). Whereas, Rekhate et lower values in comparison with the present al. (2004) and Chopade et al. (2010) reported findings.

Table 2. Growth performance and economics of growing kids in different feeding groups

\begin{tabular}{lccc} 
Parameters & $\begin{array}{c}\text { Kids on grazing } \\
\text { only }\end{array}$ & $\begin{array}{c}\text { Kids with } \\
\text { concentrate }\end{array}$ & $\begin{array}{c}\text { Kids with } \\
\text { concentrate \& } \\
\text { mineral mixture }\end{array}$ \\
\hline No. of animals & 10 & 10 & 10 \\
Initial body weight (kg) & $11.30 \pm 1.07$ & $11.06 \pm 0.94$ & $11.40 \pm 1.09$ \\
Final body weight (kg) & $14.52 \pm 0.96^{\mathrm{a}}$ & $17.42 \pm .0 .49^{\mathrm{b}}$ & $18.55 \pm 0.66^{\mathrm{c}}$ \\
Body weight gain in 90 days (kg) & $3.22 \pm 0.98^{\mathrm{a}}$ & $6.36 \pm 0.42^{\mathrm{b}}$ & $7.15 \pm 0.58^{\mathrm{c}}$ \\
Average daily weight gain (g) & $35.83 \pm 7.22^{\mathrm{a}}$ & $70.66 \pm 4.67^{\mathrm{b}}$ & $79.44 \pm 6.47^{\mathrm{c}}$ \\
Additional weight gain (kg) & - & $3.14 \pm 0.41$ & $3.93 \pm 0.49$ \\
Average cost of production(Rs.) & 475 & 610 & 632.50 \\
Cost of per kg body weight & 32.71 & 31.41 & 30.77 \\
gain(Rs.) & - & 13.50 & 14.40 \\
Total additional feed intake & & & \\
(kg/head) & - & 39.00 & 157.50 \\
Cost of additional feed intake (Rs.) & 1077 & 1432 & 491.25 \\
Additional income (Rs.) & 3.06 & 3.34 & 1522 \\
Net return (Rs./goat) & & & 3.40 \\
C:B ratio & & & \\
\hline
\end{tabular}

Group mean with different superscripts differed significantly $(\mathrm{p}<0.05)$.

Figure1. Initial body measurement of goats

\section{Initial body measurement (cm.)}

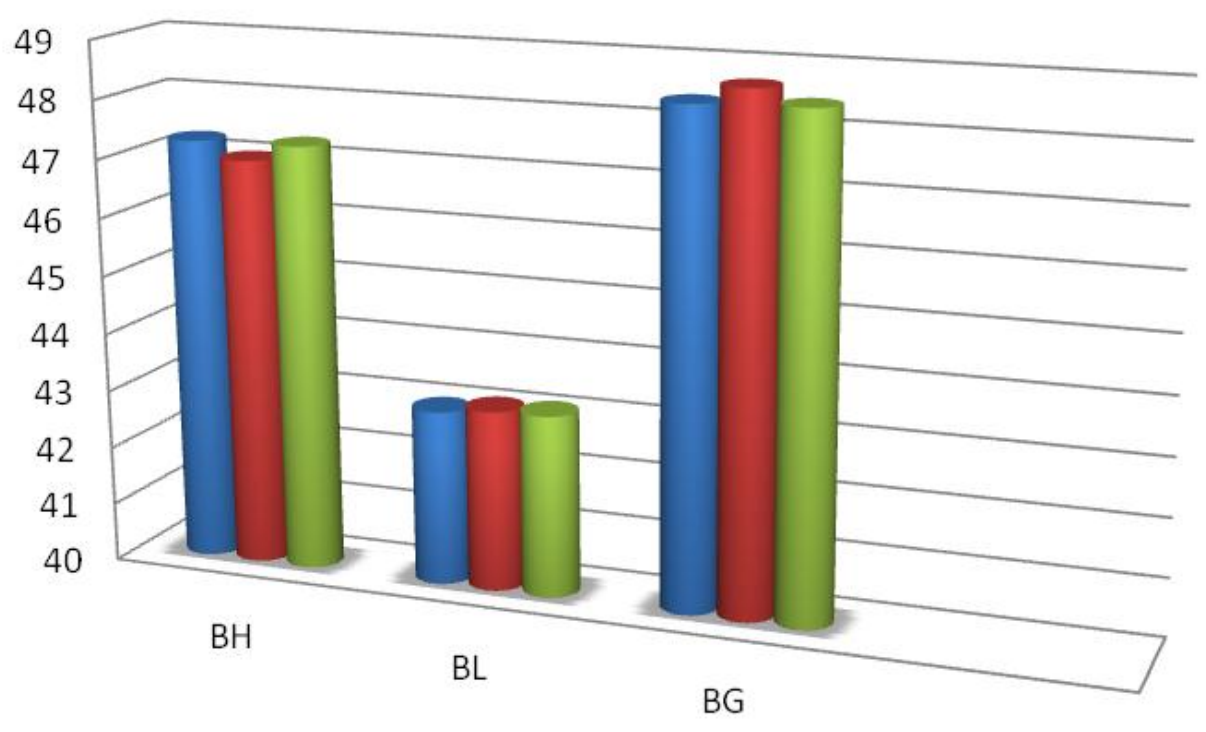


Figure2. Final body measurement of goats

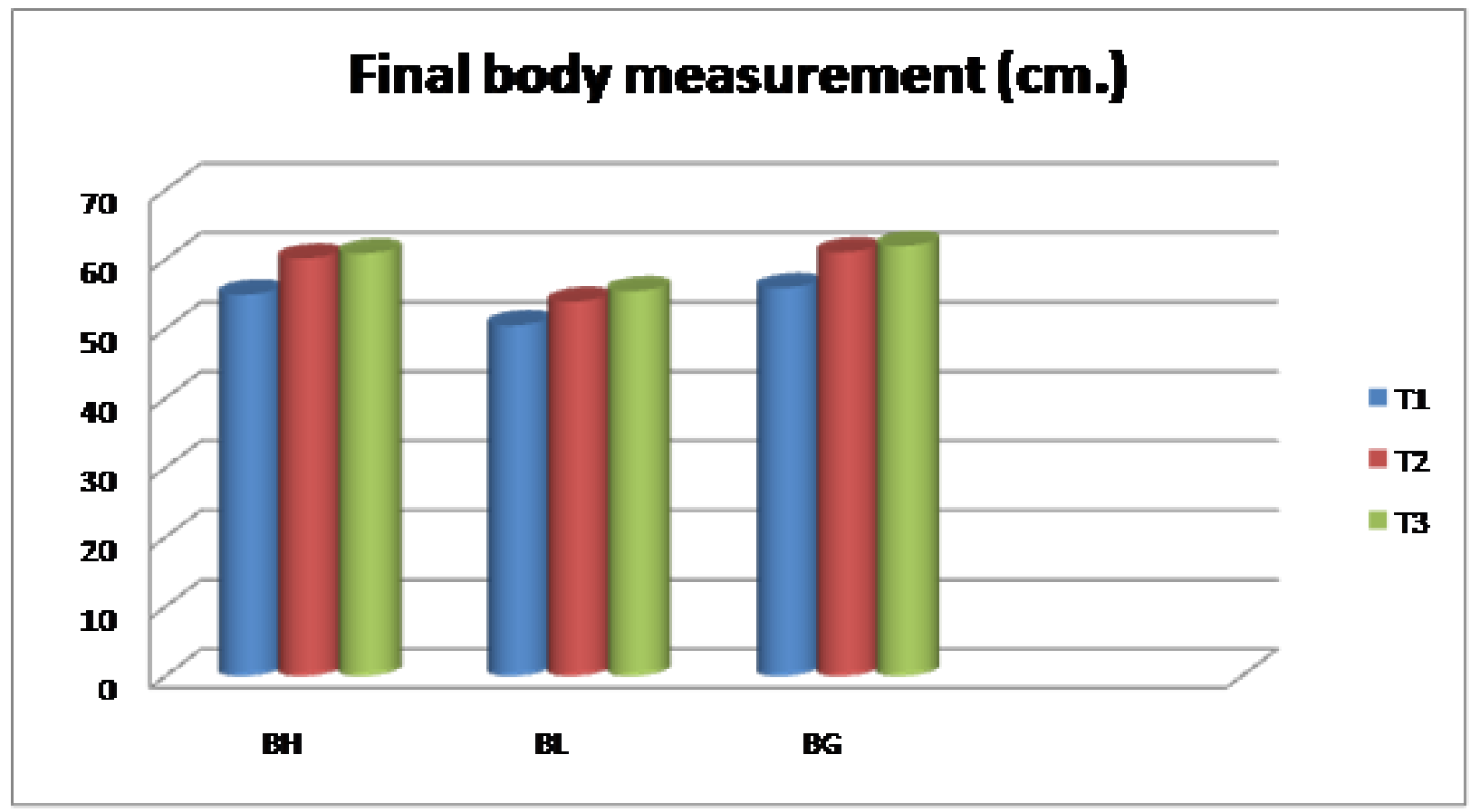

\section{Economics of feeding}

A partial budget analysis measures was used in those items of expenditure and incomes suggested by Danilo (2002). Therefore, the cost of roughage, concentrate mixture and mineral mixture have been considered. The costs of concentrate mixture and mineral mixture were calculated on the basis of market rate prevalent during the study period which was Rs. 10 and Rs. 25 per kg, respectively. Sale price of goats was Rs. 125 per one $\mathrm{kg}$ live weight. The recurring cost which included feeding and net income from sale of goats presented in Table 2. The results of study revealed that the total additional feed intake and additional cost of feed in $\mathrm{T}_{2}$ and $\mathrm{T}_{3}$ was $13.5 \mathrm{~kg}$ and $14.4 \mathrm{~kg}$ and costing Rs. 135 and Rs. 157.5 per head, respectively. The weight gain difference for the $T_{3}$ and $T_{1}$ was $4.03 \mathrm{~kg}$. The average cost of production of growing kids during study period was Rs. 475 ,

Rs. 610 and Rs. 632.50 in group $\mathrm{T}_{1}, \mathrm{~T}_{2}$ and $\mathrm{T}_{3}$, respectively. The net return from selling of goats in group $T_{2}$ and $T_{3}$ was significantly higher as compared $T_{1}$. The results of study revealed that the average cost per $\mathrm{kg}$ body weight gain was recorded Rs. 32.71 , Rs. 31.41 and Rs. 30.77 in group $T_{1}, T_{2}$ and $T_{3}$, respectively. The average 6.30 per cent reduction in cost of body weight gain $/ \mathrm{kg}$ in goats was due to the supplementation of concentrate and mineral mixture under of hot semi-arid ecosystem. The supplementation of concentrate and mineral mixture indicates that benefit cost ratio was 1:3.34 and 3.40 in group $\mathrm{T}_{2}$ and $\mathrm{T}_{3}$, which appears to be very lucrative over $\left(\mathrm{T}_{1}\right)$ traditional system of feeding (3.06). Based on the results, it may be concluded that the supplementation of feeding of concentrate and mineral mixture can be suggested to goat keepers to gain higher body weight and net 
income from growing kids under field condition.

\section{Conclusion}

It can be concluded that supplementary feeding of concentrate $(150 \mathrm{~g})$ and mineral mixture $(10 \mathrm{~g})$ to the grazing goats under semiarid field condition improves the growth performance and economic return to the goat keepers.

\section{Acknowledgement}

The authors thankfully acknowledge Director, ICAR-CIAH, Bikaner for providing facilities for conducting this research work.

\section{References}

AOAC.1995. Official Methods of Analysis.16th end. Association of Official Analytical Chemists, Washington, D.C. Chopade SR, Kalnade VH, Shelke SK \& Dandage SD. 2010. Growth performance and economics of urea treated soybean straw based pelleted complete ration in kids. Indian Journal of Animal Nutrition, 27:138-141.

Choudhary JL \& Jat HR. 2008. Effect of feeding different levels of cottonseed on the reproductive performance of Surti buffaloes. Animal Nutrition and Feed Technology, 8: 81-88.

Dangi PC. 2000. Effect of feeding urea Ammonia treated sorghum Stover on nutrient utilization by growing buffaloes. M Sc (Ag.) Thesis, Rajasthan collage of agriculture, Udaipur, India.

Khadda BS, Jadav JK, Kumar R \& Bagle BG. 2009. Goat management Practices in Panchmahal district of Gujarat. Published in proceeding of National seminar on IT application in agriculture for livelihood society of farmers held at M.P.U.A. \&.T, Udaipur dated 10-12/11/2009 pp 46-48.

Khadda BS, Lata K, Kumar R, Jadav JK \& Khajuria S 2016. Effect of supplementary feeding on productive and reproductive performance of milch buffalo under field conditions in Panchmahal district of central Gujarat. Journal of Agriculture and Ecology, 2: 51-56.

Misra AK, Subha Reddy G \& Ramkrishna YS. 2006. Participatory on farm evaluation of urea molasses mineral block as a supplement to crossbreed cows for dry season feeding in rain fed agro system of India. Livestock Research for Rural Development, 18 (2): 1-11.

Tripathi MK \& Karim SA. 2008. Minerals requirement of small ruminants with special reference to their role in rumen fermentation-A Review, 14(1): 1-47.

Prache S, Bechet G \& Thariez M. 1990. Effect of concentrate supplementation and herbage allowance on the performance of grazing suckling lambs. Grass and Forage Science, 45: 423-429.

Rekhate DH, Bhadane KP, Dhok AP, Madavi VB \& Koskewar VV. 2004. Effect of arhar (Cajanus Cajan) straw based pelleted complete feed on the performance of goats. Proceeding of the 5th ANA Conference Bangalore, 24-26 November, PP. 64.

Snedecor GW \& Cochran WG. 1994. Statistical Method, $7^{\text {th }}$ Edn. Oxford and IBH Publishing Co., Calcutta, India.

Yadav CM, Khan PM, Panwar P, Jeenagar KL, Lakhawat SS \& Nagar KC. 2010. Effect of concentrate and mineral mixture supplementation on growth performance of growing goats. Indian Journal of Small Ruminants, 16 (1): 109-110. 